\title{
BETWEEN RETROSPECT AND EXPECTATION: TRENDS AND DIMENSIONS OF EDUCATION IN EAST CENTRAL EUROPE
}

\author{
WOLFGANG MITTER \\ University of Frankfurt am Main
}

\begin{abstract}
Twenty years of transformation have gradually opened the educational systems of the East Central European countries to the common challenges of Europeanisation and Globalisation. On the other hand, the 'educational map' gives insights into existing or even re-awakened differences among the individual national patterns tracing back to socio-economic, political and cultural particularise. Recognising this fundamental tension lays the ground for the recent history of education reforms and for contextualising them within their specific societal frameworks. Special emphasis will be laid on the outcomes of reforms due to controversial approaches and political decisions within given constellations within their national ranges and their involvements in the policies of the European Union.
\end{abstract}

Key words: education reforms, Europeanisation, Globalisation, East Central European education systems

\section{Retrospect}

When the Iron Curtain was torn down at the threshold to the nineties of the twentieth century, feelings of joy and relief were spread all over the region which had been liberated from Soviet communism and totalitarianism: from the Baltic States to the Balkan Peninsula. The nations of that region had been subjected from Soviet domination as the results of the collapse of the Nazi regime and the subsequent division of hegemony between the two big power systems of that time. It is true that attempts at shaking off or at least loosening the Soviet yoke had been taken place at several times: in Poland four times, namely in 1956, 1967, 1970 and 1980, in Hungary in 1956, and in Czechoslovakia in 1968. All of them had failed, while, now at the end of the eighties, the decay of the Soviet Union, caused by internal and external factors, pointed the way to the emergence and success of liberation movements as well as to the retreat of the Soviet armies and, finally the self-resolution of the Warsaw Pact. The velvet revolution, to extend Václav Havel's 
famous catchword to the analogous events in the whole region', was supported by two essential concomitants. On the one hand it was achieved in a peaceful way which needs to be emphasised in view of many warlike and inhuman parallels in the rest of the world. On the other hand it was just that peaceful transformation that facilitated the entry of the liberated nations to the economic standards which had been reached by their Western neighbours during the preceding decades. The two exceptional cases should not be explicitly discussed in this context, namely Romania crossing the threshold under violent and somewhat dubious circumstances, and Yugoslavia, the 'autonomous' communist state whose transformation was darkened by disintegration and a decade of civil war, chauvinism and cruelty. Only the Republic of Slovenia in the Northwest of former Yugoslavia could keep out of the turbulences ${ }^{2}$

Where are the countries of East Central Europe, to identify the 'inner circle' of the former belt of Soviet 'satellites', to be placed after twenty years of post-communist transformation? As in most comparable cases, the coin reveals two sides. On the 'dark' side we get aware of socioeconomic relapses and even crises as apparently unavoidable corollaries of the new 'Western orientation' as well as with political conflicts characterising the thorny paths to democracy and civil society. On the 'bright' side, however, observations lead to perceptions of progress as regards the transformation processes in total. To explain this duality, let us begin by exemplifying the positive aspect.

\section{First example}

Though not free from temporary disturbances, all East Central European republics have managed changes of parliamentary majorities and governments due to constitutional principles, with special regard to acceptance of the outcomes of parliamentary elections.

\section{Second example}

The economic development taken as a whole, has contributed to attaining a degree of stability which, though far from being called satisfactory, can certainly stand comparisons with some of their Western counterparts, let alone the countries in South East and Eastern Europe. For the time being the measures of tackling the economic world crisis can be taken as a visible example.

1 Cesar Birzea (2008, p. 105) mentions Havel' catchword as one of corresponding terms used in other transformation countries, such as televised revolution in Romania, melancholic revolution in Hungary and singing revolution in Estonia.

2 The "Ten-day War" between the Yugoslavian army and the Slovenian home forces, following Slovenia's declaration of independence (June 26th „, 2010) came to an end by the agreed stop of the warlike actions (July 4th, 2010). 
The 'dark side' of the coin is reinforced by various aspects of disillusion, compared to the euphoric start twenty years ago. Yet, are we not reminded of the growing awareness of this euphoric substance as such, which was typical of many comments and speeches in the period of velvet revolution? Is this valuation legitimated in an affirmative way? The spontaneous answer traces back to the recent and preceding history of the region. When the nations concerned set off for building their 'new democracies', they had lived for forty years under communism, certainly a short period in regard to the millennium of their national existence of pre-existence, yet a long period as related to the life-times of the generations affected. One should never forget that the people in East Central Europe had been living for at least four decades under non-democratic conditions, when confronted with or even awakened by the 'new' challenges! This awareness becomes particularly relevant, whenever educational issues are discussed.

When entering their transformation processes the East Central European nations were united in their capacity as former members of the'enforced community' under Soviet domination. However, even under that pressure they had experienced their 'national' variations in different ways. This observation may be exemplified by comparing the developments in the post-Stalinist decades, namely between 'quasi-liberal' Poland (with her special experience of Solidarność in the eighties) and 'strictly ruled' Czechoslovakia. Education and educational research can serve as suitable comparative subjects in this connection. It is that observation which leads to the question of why the East Central European nation $s$ began their marches into the democratic future from different starting-points, the more so, as they had experienced the preceding Nazi oppression under various conditions, either directly subjected to the German occupation authorities, such as the Poles in the Generalgouvernement or ruled by quasi-independent governments, such as in Hungary and Slovakia, The Protektorat Böhmen and Mähren (Protectorate Bohemia and Moravia) took a place in-between. Accordingly, the chances of individual survival were comparatively more or less favourable, if related to the everyday lives and to the prospects of the oppressed nations, as projected by the Nazi plans for their'post-victory strategies'.

Beyond the two periods of totalitarianism we have to look back into the history of many centuries. The East Central European nations bear a heritage which is characterised by commonalities and diversities, the latter demarcating the Czech Republic, Slovakia and Hungary from Poland. Let us take a look at some historical essentials. The search for stimulating answers begins with identifying the geographic location of East Central Europe in the Eastern border zone of the Roman Catholic (and later partially Protestant) region of Europe. This retrospect traces back to the medieval roots characterised by the emergence of three spacious kingdoms with remarkable standards of internal consolidation and international reputation. The Bohemian Lands (officially: Lands of the Bohemian Crown), Poland and Hungary. Their national and cultural cohesion turned out to be solid enough to outlive even the radical 'interruptions' in later centuries, such as the Turkish occupation of the central part of Hungary (during the $16^{\text {th }}$ century), the subjugation of the Bohemian 
Lands to Hapsburg absolutism (from 1620 onward) and three partitions of Poland (last third of the $18^{\text {th }}$ century). This cohesion can be even detected in the emergence and stabilisation of the modern nation-states in the beginning $20^{\text {th }}$ century and in their revolutionary revival at the end of the eighties. It is only the Slovak case which lacks this historical continuity because of its millennium-long subjugation to Hungary (until 1918).

In the texture of the pluridimensional commonalities and diversities education (as a societal sub-system) can be definitely considered as an essential component of Central Europe's particular position. This is why it seems to be legitimate to look back into the educational history of the region and to identify it as a, though indirect, historical source of understanding the present. The past three centuries are worth to be given special attention, since they are characterised by rise and development of the modern state, even when we consider the perceptible signs of its decline in the current epoch (cf. Mitter 2004a). To return to the former periods, formal education in Central Europe can be easily related to the history of the whole of Europe in its widest meaning including the Roman Catholic territories of the continent. In the Middle Agers the establishment of schools and universities was initiated and sponsored by the Roman Catholic Church, later on rivalled by kings and princes. In this context the foundation of the Universities of Prague (1348), Cracow (1364) and Pécs (1367) proved to be prospective events affirming the active participation of the East Central European kingdoms in Europe's progress in education and culture. The history of commonalities was continued by the course of Reformation and Counter Reformation that indicates some similarities, in particular with regard to the educational efforts of the Jesuit order on the one hand, while on the other hand Jan Amos Comenius' various activities in the Bohemian Lands as well as in Poland and Hungary considerably contributed to the educational progress in those countries.

It is, however, the period of Enlightenment and Enlightened Absolutism that has set a landmark to educational history of the East Central European region on the whole. It consists of political initiatives, theoretical concepts and practical measures. At the same time, however, the commonalities to be observed have to be opposed to the differences of the contextual political frameworks, as regards the Hapsburg Empire on the one hand, the Rzeczpospolita Polska (Polish Republic, in its constitutional statues of Electoral Kingdom) on the other. In the Hapsburg Empire the Enlightened Absolutism under Maria Theresia and Joseph II contributed to the formation of the modern state including the establishment of an effective state education system due to the rulers' express intentions (Heckel \& Avenarius, 1986, p. 3):

to instruct the subject in the most necessary cultural skills to enable him to read the directions given by the authorities, to make himself understood in the State of civil servants (Beamtenstaat) and, above all, to play his part in the growth of the State's welfare through economic efficiency... 
In this context it should be anticipated that, in principle, the responsibilities of the modern state, as defined by this statement, were taken over by Czechoslovakia and Hungary (and Austria) in 1918 as independent succession states of the Hapsburg Empire, in that the 'subject' was transformed to the 'citizen' as the addressee of the State's educational efforts (cf. Heyneman, 2002, pp.16-18). It is true that Hungary had assumed a special status within the Hapsburg Empire after the Turkish occupation (cf. Hives et al., 2007, p. 341). This is why Maria Theresia's educational reforms were materialised in separate legal directions: the Allgemeine Schulordnung für die deutschen Normal-, Haupt- und Trivialschulen in sämtlichen $K$. und K. Laendern" (General School Order for the German Normal, Secondary and Elementary Schools) for the Western and Northern provinces of the Empire in 1774 and the Ratio Educationis (The Educational Plan) for the provinces of the Hungarian Kingdom in 1777. Her and her son Joseph's educational policies pointed the way to the progressive development of education throughout the nineteenth century. In particular, the schools in the Bohemian Lands reached high standards and were highly reputed all over Europe (and the rest of the world), from the kindergartens to the institutions of higher education (cf. Mitter, 2004b, p. 27).

In the $18^{\text {th }}$ century the development of education in Poland resembled that of her Hapsburg's counterparts, insofar as it was distinguished by remarkable efforts initiated by the authorities to build an education system rooting in the ideas of Enlightenment. The most significant achievement of this policy was the formation of the National Educational Committee in 1773 which has taken its place in European educational history as the first institutional manifestation of a Ministry of Education. However, this promising process came to an early end with the second and third partitions of the country (the first had been effected in 1772 already), and formal education was totally subjected to legislation and governance by the occupying powers (Russia, Prussia and the Hapsburg Empire). It is true that in the Austrian part (Galicia) Polish-medium schools (up to the level of higher education) were included in the aforementioned Hapsburg policies, but, in the Prussian and Russian parts the mainstream education system was under the permanent pressure of denationalisation in terms of language, culture and historical awareness, while on the other hand it "was commonly accompanied by unofficial private educational institutions that strove to preserve a national identity" (Hörner \& Nowosad, 2007, p. 590). This peculiarity of Polish education resulted in the formation of widely illegal, but effective parallel institutions, established at the grassroots by committed teachers, educators and other educated members of the middle class. To a remarkable degree all these counter-activities were initiated or supported by the Roman Catholic Church. In legal forms they should enrich the revival of education throughout the period of independence between the two World Wars and even survive and prove their vital strength in the periods of suppression during and after World War Il under the Nazi and Soviet regimes. 


\section{Identifying East Central Europe}

Since the changes of the 'European $\mathrm{map}^{\prime}$ at the threshold to the nineties the terminological issue of defining East Central Europe has been widely and controversially discussed. Yet, its application for part of the post-communist region of the European Union, as used in the present chapter according to the self-definition of the liberated countries concerned, is not cogent, neither under geographical nor under historical aspects. There are three criteria to be explored in this context. Firstly, this definition necessarily suggests the question of an existing 'West European' counterpart. Accordingly, in the interim period between the two World Wars Germany and Austria were considered to be parts of Central Europe in political literature and journalism. In the discussion of today this allocation has not entirely disappeared, but has been widely confined and is now applied, as pars pro toto, to the Region comprising the Czech Republic, Slovakia, Hungary and Poland. Secondly, as regards the historical roots of the region, the door is open to reflecting a wider concept of East Central Europe, as has been proposed by Cesar Birzea (2008, pp. 105-113). On the one hand the Baltic States share their affiliation to their Southern neighbours, both to the medieval Holy Roman Empire of German Nation, as regards the territories of modern Estonia and Latvia, and to Lithuania's close union with Poland for several centuries. Thirdly, in former periods the religious borders separating Roman Catholics from their Orthodox and Moslem neighbours in the South East region of Europe (Romania, Bulgaria, the Eastern parts of former Yugoslavia) played an essential role in regard of the applied terminology. It is true that this criterion has lost its former political significance against the concept of independent nation-states, but has maintained its place in the encounter of religions and cultures. To end up the present excursion into the field of terminology, contemporary historians, particularly in Germany and the United Kingdom, tend to apply the notion of East Central Europe (Ostmitteleuropa) in order to emphasise the peculiar geographical, economic and cultural position of the region in question.

The complexity of the discussion is event widened by relating this concept to the whole of Europe and its demarcation to the other world regions, in geographical, socioeconomic and cultural terms. As regards the current debate, may if suffice to exemplify it by the following, as it seems, both original and appropriate comment made by the British historian Anthony Pagden and cited by his Polish colleague Piotr Sztompka: "Europeans are, I suspect, unusual in sharing in this way a sense that it might be possible to belong to something larger that the family, the tribe, the community, or the nation, yet smaller and more culturally specific than 'humanity'..." (Pagden, 2002, pp. 33-54; Sztompka, 2004, p. 485). In this sense the people in East Central Europe can be easily identified as members of the wider Europe on the whole.

In an extended view it is tempting in include East Germany in the current discussion. On the one hand this temptation traces back to the aforementioned definition of the Central European region during the interim period between the two World Wars. On the other hand the German Democratic Republic (GDR), 
established by the Soviet Union on her occupied territory in 1949, shared with her Eastern and Southern neighbours the politically and ideologically based status of a 'Socialist' republic. There was, however, one significant particularity. At not period of her existence the GDR was able to enforce a'feeling of national identity' among her population which needs to be considered as an essential item, because it was just this trait that strongly constituted the national self-awareness of her neighbours even under the oppression of both totalitarian systems. Moreover, this divergence was compensated by the permanent influence exercised by the Federal Republic of (Western) Germany by ways of political statements and appeals, by the transmission of the media and, as far as allowed, by interpersonal contacts across the border all over the decades of the German partition. Both factors laid the ground for the survival of an all-German identity which, though far from being unlimited and undisturbed, survived the four decades of partition and eventually led to the victory of the 'reunification project' against a few concepts of a'third path' in form of a'truly democratic' East German state, as was suggested in the transition year (1989/90), This decision has been materialised in the inclusion of all the legal, administrative and economic essentials in the constitutional structure and its acceptance by the vast majority of the re-united Federal Republic, notwithstanding the continuation of resentments among the former'socialist' elites. According to that particular form of transformation, the education systems of the East German Laender (states), as regards their structural, curricular and pedagogic characteristics, were established as components of the German federalism. Yet, the aforementioned experience of having spent part or even one's whole lifetime under communist rule has not left attitudes and emotions in East Germany untouched which makes comparative studies between East Germany and East Central Europe reasonable with regard to the analogies and differences to be investigated, Education is expressly included in this desideratum (cf. Mitter, 2005).

\section{The Place of Education in Transformation Process}

When talking about the part education plays in transformation processes, it seems to be legitimate to take a glance at some significant items. In the social sciences the discussion of this issue is frequently narrowed to the supporting function of education in its relations to the political, socio-economic and cultural trends within the societal super-system. This widespread view seems to explain the comparatively weak attention paid to developments at the macro- and microlevels of education against the 'more significant' trends at the socioeconomic and political levels - with all the fatal corollaries for the implementation of legislative and administrative reforms as regards, for instance, insufficient or misdirected budgets or inadequacies in teacher education. Such deficient approaches neglect the functions in which education is directly involved with its co-operating function in decisions and the implementations, let alone the chances of success concerning educational reforms for the sake of adjusting the systems in total or parts of them to the changing societal conditions and requirements. 
This consideration traces back to the base of human-existence at all and is particularly relevant in societal shifts such as the transformation in East Central Europe. Individuals think and act, and in these capacities they are exposed to the exceptional challenges emerging in transformation processes. It is true that the political and economic élites are mostly affected by these challenges, but the 'common citizen' does not remain untouched either, as public actions (debates, demonstrations etc.) and elections indicate. Furthermore, the forms and standards of human thoughts and actions are essentially dependent on the outcomes of how the individuals have been trained and educated and what they have learned in the course of their childhood and adolescence in the 'old' system, in the given case under communist rule. The ranges of the socialisation and education processes are not limited to the institutional establishments, such as schools and youth organisations, but also, though in an indirect way, affect families, peer groups, working places and, under special circumstances, as particularly given in Poland, churches. In this context, one has to distinguish people's diverse attitudes: from (voluntary or enforced) acceptance of the communist norms via opportunist adjustment to passive or even active resistance.

Finally, people's capacities as consumers of commodities and media must not be disregarded in this connection. As 'products' of these overarching education and learning processes they enter the 'new' (in this case democratic) system, whereby in a general estimation it is irrelevant at which age they pass the threshold. What is relevant, however, is their individual mental attitudes to the challenges of transformation: Are they prepared and willing to devote their capacities to the required reforms and innovations, or has the impact of the 'old' system turned out to be so strong as to make them join those who want to brake, stop or even pervert the transformation, as is demonstrated by the survival and continuation of 'communist' and 'leftist' parties? This is why thoughts, intentions and actions of the individuals concerned outlast 'revolutionary' shifts and, moreover, exercise great influence on the start of state and society into the 'new' system with all its effects of success or failure. The revival of communist or leftist groupings or even political parties (as in the Czech Republic) exemplifies the political level of such persisting forces. Needless to emphasise that education is directly involved in these processes and, therefore, in the results of transformation.

\section{Criteria of Educational Transformation}

The criteria outlining the current stage of education in the East Central European countries, related to its departure from the 'socialist' era, are presented in the following survey (cf. Mitter, 2005, Steier-Jordan 2003, Walterová 2007). Although the periodic (or unforeseen) changes of parliamentary majorities and governmental coalitions have often been accompanied by vacillations concerning the setting of priorities and by controversial debates, the external observer is able to identify some essential features of a continuity to be referred to all the four countries. It goes without saying that the following outline does not claim any completeness. ${ }^{3}$ 


\section{Decentralisation and deregulation of governance}

The Education Act which had been passed in Hungary in 1985, i. e. already in the pre-transformation period, opened the door to a trend aimed at deregulating governance in the education systems of the East Central European region from the top to the provincial and local bottom. In 1990 this trend was taken up in Hungary by the first democratic government. Poland joined it on the base of its 'pre--history' of communal self-government. In the Czech Republic and Slovakia similar initiatives began later. Regardless of the aforementioned governmental changes one can assume that decentralisation and deregulation have proved to be a continuous feature of commonality. It comprises the transfer of decision-making from the centralised administration to self-governing competencies of the local and school levels with special regard to management and curricula. Trans-national differences have been caused by preferences within the national authorities for particular strategies and measures and by economic bottlenecks on the one hand, and existing experiences with a well-operating administration on the other.

\section{Finance of education; tendencies of privatisation}

In all the four East Central European countries the deregulating measures have been simultaneously confined and stimulated by budgetary deficits. In general the introduction of market economy led to economies entailing remarkable curtailments in the area of education. These procedures have continued until today and even been reinforced by the global financial crisis of our days with their impacts on the national (and EU's) policies. Austerity does not only debase the equipment of many schools, but also tends to freeze the low teacher salaries and to make qualified teachers to look for situations in the private economic sector. Furthermore, it exerts a detrimental effect on the provincial and local school budgets, since these are widely defrayed by the national budgets. However, the free entry to public primary and secondary schools has not been affected. In this respect educational policies do not only continue the 'socialist heritage', but also act in agreement with the constitutional and legal provisions which determine educational policies in Western Europe. At the level of higher education, however, tendencies of charging study fees are to be observed, also in agreement with

3 Beside the titles quoted in the main text, the author is particularly obliged to the members of the comparative research project "The development and State of Educational Systems in the Visegrad Countries in the Context of Social Transformation" which has been conducted at the Charles University (Prague) with Eliška Walterová as chair-woman. While she herself wrote the key article, the country studies were elaborated by David Greger and Eliška Walterová (Czech Republic), Gábor Halász (Hungary), Andrzej Janowski (Poland), Beata Kosová and Štefan Porubský (Slovakia). Further basic help to the present paragraph has been provided by the authors of the handbook "The Education Systems of Europe", ed. by Wolfgang Hörner, Hans Döbert, Botho von Kopp, Wolfgang Mitter: Jan Průcha (Czech Republic), Tamás Hives, Tamás Kozma, Imre Radacsi and Magdolna Rébay (Hungary), Wolfgang Hörner and Inetta Nowosad (Poland), Štefan Švec and Mária Hrabinská (Slovakia). 
recognisable tendencies in parts of Western Europe. In this context special mention should be made of Poland, where universities and other higher education institutions have established sections for those fee-paying students who have not passed their entrance examination.

Privatisation was introduced into the education systems in the early stage of transformation already, as a radical response to the rigid state monopoly exercised by the 'old' system. Though with different intensity, it covers all school levels: kindergartens, primary and secondary schools as well as - mainly - vocational training establishments and institutions of higher education. Furthermore, private institutions offer in-service training courses for teachers being in a need for upgrading their qualifications. To stabilise and control the expansion of the private sector, the ministries of education have intensified the directions for accreditation, particularly for the universities. As regards the developments of the private sector at the levels of primary and secondary education, the quantities have remained rather marginal which, however, does not concern the qualities of individual schools. There are four types of private schools to be specified. Firstly, the big religious communities have opened (or re-opened) schools of their own. Secondly, schools have been founded by private providers on the base of distinctive educational philosophies. Among them Rudolf Steiner (Waldorf) Schools and Montessori Schools have placed themselves most successfully. Thirdly, in Poland some private schools fill gaps which have been left open in the public sector. Finally, there are private schools which have been opened on a purely commercial base. They charge especially high fees and frequently occupy teachers of public schools who thus get the desired chance of a 'second job'.

\section{Structural reforms}

Transformation has effected the departure of the 'socialist unity school' which had dominated the structure of compulsory education during the communist period. This principle, however, had been actually undermined by the existence of special schools with intensified and extended instruction in sciences and foreign languages. The structural reforms of the nineties were mainly aimed at reorganising the lower secondary level where the current 'school map' shows three arrangements.

- The lower secondary level has been maintained as part of the existing nineyear comprehensive schools for the majority of pupils in the Czech Republic, Hungary and Slovakia.

- In Poland the lower secondary level has been separated from the five-year primary school and organised in form in a three-year gymnasium as one of the main components of the school reform of 1998 which was implemented from 1999 onward.

- In the Czech Republic, Hungary and Slovakia the traditional 'long' gymnasiums (not to be confused with the aforementioned'new' gymnasiums with the same name in Poland)have been revived in form of eight- or six- 
year institutions. The acceptance of this system is not undisputed, as had been demonstrated by the educational policies in the Czech Republic at the threshold to the $21^{\text {st }}$ century. The former social-democratic government had a White Book elaborated with recommendations for a compulsory comprehensive public secondary school, but was unable to get its planned reform carried through the parliament. This is why the maintenance of the 'long' gymnasiums is likely to be consolidated for the foreseeable future, since it is supported not only by traditional conservatives, but also by the adherents of 'market liberalism'

Vocational education at the upper secondary level has been most affected by the structural reforms until now. The complexity of the reforms is caused by the radical changes in the economic system which has no demand any more for workforce having been trained according to the former requirements of the rigid planned economy. It is interested in differentiated, flexible and modulated structures. It seems to be evident that vocational education has to cope with particularly thorough and dynamic reforms.

\section{Curricular reforms}

The curricula have undergone comprehensive changes, too, during the past two decades. This is true of central regulations by the ministries of education as well as the numerous projects that have been conducted at many schools, thanks to the aforementioned deregulation policies. The reforms began with 'cleansing' of the ideologically overloaded syllabi and textbooks, in particular in the subjects of history, civics, geography and mother tongue. In the subsequent years all subjects were modernised. There have been thorough innovations in foreign language instruction in a twofold way, namely by a differentiated choice of languages, connected with the abolishment of the former monopoly of Russian as first foreign language, and by promotion of methods focused on the acquirement of modern language practice, including the recruitment of native teachers. Special mention is needed of the advancement of the electronic media into the classrooms, though this requirement is often delayed by budgetary curtailments. As regards the curriculum reforms in total, the new provisions consist of disentangling the overloaded subject matter and of introducing innovative learning standards to be oriented to the transmission of cognitive competencies. The implementation of these innovations is often checked by inadequate teacher education, let alone deficits in the field of in-service-training. The partially unsatisfactory outcome of the first three PISA evaluations (see next paragraph) are likely to stimulate the reform debates, which, however, is also true of West European education systems. In general, the current curricular reforms indicate the entry of the East Central European countries into European and global trends (to be tackled below), including continual emergence of resistances and disturbing factors. Finally, special attention is demanded by the general position of religious instruction which reveals different approaches, where 
Poland takes an exceptional place, in that religious instruction has been granted the status of an ordinary subject up to the termination of upper secondary education.

\section{Evaluations and examinations}

The changes having been effected both in school management and large-scale assessment are worth articulating insofar, as they are directly related to the goal of quality assurance as a contribution to an efficient conveyance of competencies to be required in the modern world. In this respect the development follows the global trend based upon the assumption that the demands raised by the modern society for adequate workforce (at all levels of the labour market) could be optimally fulfilled by competing education systems organising school instruction according to trans-national learning standards and subjecting it to continual evaluations mainly based upon standardised achievement tests. The procedures are oriented at the norms of objectivity (by identifying system-related standards), anonymity (by external - state or private - testing agencies) and quantification (by application of hared testing instruments). The innovations continuing in all states of the region comprise evaluations of individual schools and local, regional and national educational units as well as individual and collective achievements tested in classes and age-groups.

Particular attention should be paid to the participation of the East Central European countries in the international school assessments in view of its diametric outcomes which are, in this context, presented by exemplary data.. The Czech Republic and Hungary took part in the TIMMS 3 Study with over-average success, while their outcomes of PISA 2000 indicated negative scores: in reading comprehension below average for all of them, in mathematics below an average for the Czech Republic, below average for Hungary and Poland. Only the outcomes in sciences resulted above average in the Czech Republic and on an average in Hungary. The above-average outcome for Poland from PISA 2003 have been ascribed to the school reform of 1998, in particular the introduction of the three-year gymnasium with new curricula. Special attention is finally required by the striking contrasts of the data between above average in mathematics and sciences against below average In total, the oscillating findings mirror, as has been expressed in representative comments, the transformation processes in the education systems as such in regard of their administrative, structural and curricular features, but also, what has been often neglected, changes in the test arrangements and competence definitions made by the international expert groups. This is particularly true of the targets from knowledge reproduction to the proof of cognitive competences.

The impacts of the innovations on evaluation necessarily entail the outcomes of qualification awards, in particular to be observed in the terminal examinations of the lower and upper levels of secondary education. The current trend gives insight into various approaches resulting from compromises between 'traditionalists' and 'modernisers'. They can be exemplified by the adherence to traditional forms of essay writing and oral examinations versus the reduction of these (above all, in 
foreign languages) and the application of standardised testing. A second field of conflict consists the - at least partial - maintenance of school- and teacher-centred organisation of examinations (according to the 'Central European'tradition) against centralised procedures (to be compared to the French and British practice). There is a clear trend in favour of the 'modernisers' to be hardly delayed by articulate resistance by the 'traditionalists'. Finally, there are trends of upgrading maturity examinations as terminal awards of upper secondary learning by abolition of the hitherto dominant duality between these and the university entrance examinations.

\section{Developments at the level of higher education}

The present article is focused on the general section of the primary and secondary levels. Yet, they should be extended to an outline of basic issues concerning transformation at the level of higher education. the more so as the rapid expansion of this level, having been distinctly demanded by policy-makers and representatives of the economic system, casts its increasing shadows on the lower levels of the education systems. Recent findings demonstrate that in higher education the impacts of transformation are most manifest and far-reaching. Above all, this is true of the enactment of laws and decrees as well as their implementation. These are the most significant reforms aiming at:

- Changing the legal status of universities in the direction of self-governing competencies and differentiated structures.

- The return of research from the widely occupied monopolies of the Academies of Sciences to the universities.

- Finance in co-operation with firms and banks (as far as possible).

- Curricular innovations by disentangling the former rigid syllabi to modern teaching and learning schemes, in particular in modular arrangements.

- The introduction of the three-tier graduation structures (Bachelor, Master, Doctor) which have been modelled on the Anglo-Saxon higher education systems and elaborated in the course of the Bologna process. This trend, however, is not uncontested, in particular in regard of the new graduation structure including the departure from the 'well-tried' diplomas and its acceptance by the labour market.

\section{The Four-Level Pattern of Change}

Analysing commonalities and diversities of the nation-bound transformation processes in East Central Europe is complicated by their inclusion in super-ordinate trends on the European and global scenes which, on their part, are paralleled by the overarching trend of world-wide modernisation in the field of science, technology, economy as well as social relations and actions. Actually, we get confronted with four levels of change giving insight into the complexity of the transformation processes with their progressive directions and setbacks. Furthermore, the complication of 
the analysis is reinforced by the emergence of counter-trends at each of the four levels. The complex change in total can be reduced to the following antithetic configurations with their specific impacts on the East Central European region.

\section{The national level}

At the national level the march of the East European nations into the challenges of democracy, civil society and market economy is counteracted by both the survival of the 'socialist heritage' and the revival of attitudes and feelings tracing back to the 'pre-socialist' periods. Features of these traces can be primarily perceived in manifestations of history-based patriotism and nationalism which are mirrored in political speeches, publications and actions of various kinds as well as in curricula and textbooks. They reach the everyday school practice e. g. in how teachers use the monopoly of interpretation during and outside the classroom instruction. However; it would be one-sided to confine this counter-trend to East Central Europe against similar trends in Western Europe and on other continents.

\section{The European level}

"Back to Europe" has been identified by Cesar Birzea as "one of the influential slogans ... on the background of post-revolutionary euphoria" $(2008$, p. 107). It is true that "a sign of membership was not listed in any of the political programmes or documents of the 1989 revolutions" (ibid.) Yet, this attitude should quickly give way to opposite policies, formally leading to the accession of the Czech Republic, Hungary, Poland and Slovakia (as well as Slovenia and the Baltic States) to the European Union in 2004; Bulgaria and Romanian followed in 2007. The question of whether this accession should be called "the second transition" (cf. Birzea, 2009, p. 105) or, in a more cautious interpretation, regarded as the second step following the first step of the revolutionary upheavals, should be left open ${ }^{4}$. The importance of the inclusion of the East Central European region in the trend of Europeanisaton as such, however, is incontestable, the more so as the accession of the four countries had been preceded by an intense 'examination procedure' including requirements of educational reforms. As a cogent consequence of this accession process, the 'new' member countries have been incorporated in the EU's educational policies, based upon the Treaty of Maastricht of 1993 and the Open Method of Co-ordination (OMC) resolved by the Lisbon Summit of 2000.

Moreover, they have been invited to take part in the multifarious activities extending the EU's sphere of action below the 'upper level' of formal decision-

4 As regards the identification of historical periods, the transformation research offers several approaches. The aforementioned comparative project (vid. footnote 3 ) follows the scheme which was devised by Jiři Kotásek, the initiator of the project (who passed away in 2006). It consists of the periods of deconstruction, partial stabilisation, reconstruction, implementation of systemic reform. Alternative models periodising educational transformation in East Central Europe have been presented, among others, by Cesar Birzea and Janusz Tomiak. Cf. Mitter, W. 2003, pp. 83-85. 
making. The 'lower level' is demonstrated by exchange programmes for teachers and students in higher education as well as of trainers and trainees in vocational education of the secondary and post-secondary levels. The European Commission continually publishes memoranda whose medium-term impacts on the educational policies of the member-states should not be underestimated, the less so as those publishing activities are getting associated, in particular in the framework of OMC, with the invasion of international evaluations of achievement (IEA, PISA, etc.) into the decision-making procedures both of the European Union and its member-states. This trend must be taken very seriously, although the participation of the national governments remains formally based on 'voluntary' decisions. In this connection further mention should be made about the comprehensive Commission Report of November 2001 containing the programme of "creating a European space of lifelong learning" (Eurydice, 2001). All these documents reveal an actual change in the self-identification of the European Union, namely to grow, beyond economic, social and political integration, into "an educational and cultural community" (cf. Hochbaum, 1993) and, consequently, into a 'European space'. Finally, the European Commission has engaged in financing innovatory projects concerning school management, curricular development, education for integrating migrant children and youth and other educational fields. All these projects, to be allocated to the 'medium level' of the European Union's activities, are aimed at contributing to the improvement of their achievement standards and to the harmonisation of the education systems on the whole. As regards the pursuit of these policies, the East Central European countries and the other 'newcomers' are definitely treated as privileged addressees. Weighing the totality of all these promoting activities, one feels legitimated to the comment that these projects are likely to be the most effective achievements initiated by the European Union to ameliorate the education systems in that region and to adjust them to the Post-Lisbon strategies. Summing up, the 'European space' has taken concrete contours. However, these should not be overestimated against the impacts coming from the United States, particularly in higher education.

A parallel stream of harmonising education in Europe, and that at the level of higher education, has been initiated by the Bologna Declaration signed by the European Ministers of Education and Culture in 1999. In the meantime it has considerably expanded beyond the borders of Europe by the accession of numerous non-European countries. The implementation of its aims concerns the deregulation of governmental competencies in favour of self-governing ones by the university bodies, the harmonisation of qualifications by installing a cross-national system of graduations (bachelor, master, doctor) and, finally, the introduction of compulsory guidelines for accreditations to be acknowledged all over the 'Bologna purview'. It is true that the Bologna Declaration has reached cross-continental range which should not make us disregard, however, its particular European origin and its relevance for the harmonisation of higher education in the European Union including the East Central European countries. 


\section{The global Level}

At the global level educational policies and educational practice get increasingly determined by the demand for socio-economic competitiveness, due to the dominating ideology of neo-liberalism. Consequently, the market pervades school management and planning and, moreover, even reaches the everyday classroom instruction by internet and other media. The border-crossing and market-driven training and qualification programmes, emerging in the framework of the World Trade Organisation (WTO) and the General Agreement of Trade and Services (GATS), reinforce this process. It is true that this worldwide trend contributes to learning and cognitive achievement. It would be erroneous though to underestimate the dark sides of this influence caused by the impacts of globalisation on education and learning. Schools have to cope with an increasing divergence between standardised assessment and traditional school philosophies (e.g. neo-humanism) having essentially shaped the 'intern core' of education and learning aimed at the pupils' mental and moral development and identity. East Central Europe has been greatly affected by this divergence, the more so, as the neo-humanistic message had exerted focal influence on the curricula and attitudes of teachers and pupils and their mutual relationships, while with the progress of the contemporary utilitarian conceptions they tend to become obsolete. The counter-trend of educational pluralism, as part of localisation, is signalled by recent advancement private schools based on individual-oriented and humanistic conceptions. ${ }^{5}$ Furthermore, the growing demand for self-government must be observed in this context. Its subjects are to be identified in local communities, schools and governing boards, parent committees, associations of the civic society and, last but not least, inside the schools with head-teachers, teachers and further educational staff, and, finally, pupils. However, in the context of this presentation one should not forget the 'counter trend within this counter-trend', namely the attempts of central educational authorities to use self-government for unburdening the state budgets by loading schools, governing boards, sponsors and parents with new responsibilities, in particularly in the areas of budget controlling and fund raising.

\section{The level of modernisation}

Modernisation, whose importance in the context of the present article should be limited to general comments, differs from the three other trends, in that it is not bound to any spatial dimension. It comprises all advancements in modern society. In the education systems its impacts are particularly relevant in the educational management and finance as well as the development of information and communication technologies both in steering centres (e. g. school directorates) and classrooms. Special emphasis should be laid on the modern patterns of evaluation

5 In this context the parallel increase of purely commercialised schools with their utilitarian philosophies remains outside the present discussion. 
and assessment. On the other hand the post-modernist trend comes to light in the catchwords of 'decentralisation', 'deregulation', 'self-government' and 'autonomy'. The tension between the two poles may be exemplified by the opposition of 'deregulation' of governance in education to centralised quality assurance by standardised assessment procedures and centralised examination rules.

As regards the part of education in the four-level pattern of change, suffice it to propose some illustrative examples:

- Learning projects directly aimed at promoting international co-operation and trans-national (e.g. European) commitment have to cope with counteracting resentments among members of the adult generation (teachers, parents) focused on the perseverance of nationalist resentments and intolerance in its various manifestations.

- Advancing integration of educational policies, as conceived and implemented by the European Union is paralleled by competing strategies toward stabilisation of national particularities in form of laws, orders and curricula.

- Border-crossing teaching and learning experiences and migration processes have to compete with the advancement of self-government at the grassroots of individual schools.

- Modern information and communication technologies in schools and classrooms as well as respective shifts in educational management collide with individualised and differentiated learning processes.

It would be erroneous to disregard the positive elements of the antithetic configurations emerging in these examples. They can serve as items of progress, harmonisation and reconciliation, provided they are based upon the core values of human rights and tolerance. If these, however, are neglected, they are exposed to conflicts.

\section{Concluding Considerations: Quo Vadis, East Central Europe?}

The shift of paradigm challenging the societies of the East Central European countries in view of the 'four-level' transformation processes, has affected the education system with all its power. The level of Europeanisation materialised by the accession of the four countries to the European Union, should awaken our particular attention in the following concluding considerations. In this context the German sociologist Barbara Lippert has commented this shift of paradigm by applying a three-dimensional model which pluralises the trend to Europeanisation in a plausible approach, namely in her article with the symptomatic title"Sternstunde oder Stolpersteine? Erweiterung und europäischen Integration" (Sidereal Hour or Stumbling Stones? Expansion and European Integration) (Lippert, 2004, p. 60) 
At first the newcomers must develop a feeling of ownership in the success and negotiation story of the European integration. Therefore they are in need of target-points. One can think that for the most new members the projects are to be looked for rather in the context of the 'Lisbon strategies' concerning the dynamisation of growth and competiveness as well as the struggle against unemployment than in the development of the EU as a global actor. The new members will strongly discuss the historical dimension of the European integration (reconciliation according to the German-French example) and an answer to war and violence (among the European countries) on the one hand, and the pragmatic dimension (the Single Market and the sectoral policies) which, consequently, must be preserved and continued at the transition to the strategic dimension...

This three-dimensional model can be transferred to the curriculum planning of the schools in East Central Europe. In the historical view we discuss the comparability of the national, ethnic, religious, political and cultural traditions with the claims for integration confronting the young generation with the 'wider' Europe. The pragmatic view concentrates on the question of how the modern globalisation can be harmonised with the European particularities, defined by Anthony Pagden. These become manifest subjectively in the implementation of economic, political and socio-cultural desiderata, subjectively in the search of a 'European' identity. The transfer of the strategic view emerging on top of both the preceding views to the curricular issue points to the target-setting in instruction and education with respect to preparing the young generation to making national, European and universal (global) tasks compatible in their thoughts and actions.

Discussing the strategic aspect immediately leads to the identity issue including its conflict potentials. In this context it is worth resuming Piotr Stompka's analysis and, in particular his concluding considerations. He pleads for breaking up the ages-old unity of national (tribal, ethnic) identities and citizenship and thinks this approach to be the "best way to assure the development of a balanced and 'trouble-free' identity" (2004, p. 394). In the sociological literature the new stage of identity is analysed within the concept of "multiple identity", as presented by Sztompka's following reflections (ibid.):

People craft themselves, rather than receiving themselves ready-made. Transnational, continental, or even global identities appear as new additional options, but do not necessarily eliminate other identities or orientations linked to regions, nation, ethics, religion, occupation, gender, sexual preferences, life styles, consumer communities, fashion-communities, leisure communities, etc. Multiple identities imply the enrichment of bonds, social networks and opportunities of experience and expression.

There is no doubt that the development of multiple identities appeals to European education in total. In this respect teachers and pupils in the East Central European countries have a lot to catch up on their way of attaining standards and attitudes that have been, though insufficiently too, reached in Western Europe. This observation comes out in Barbara Lippert's perception of "stumble stones". In the context of the present analysis it points to the aforementioned gaps in the structural and, the more so, in the curricular and attitudinal areas of educational research, policy-making and everyday practice. The retrospect to the past twenty years, however, gives insight into the complementary perception of "sidereal 
hours" as well. They become manifest in the openness to innovations, for instance in ways how to deal with self-government at the grassroots of the education systems, or in successful participation in the international assessment studies of the past two decades. The outcomes of the comparative study The transformation of education systems in the Visegrad countries, conducted by Eliška Walterová and her international team, provides a source revealing, after all, that "Back to Europe" cannot be solely dismissed as unrealistic expectation.

\section{References}

Birzea, C. (2008). "Back to Europe" and the second transition in Eastern Central Europe. Orbis Scholae, 2(2), 105-119.

Eurydice European Unit (ed.) (2001). National actions to implement lifelong learning in Europe. Brussels: Eurydice / Thessaloniki: CEDEFOP.

Greger, D. \& Walterová, E. (2007). In pursuit of educational change: Transformation in the Czech Republic. Orbis Scholae, 1(2), 11-44.

Halász, G. (2007). From deconstruction to systemic reform: Educational transformation in Hungary. Orbis Scholae, 1(2), 45-79.

Heckel, H. (1986). Schulrechtskunde [School law], $6^{\text {th }}$ entirely revised edition by H. Avenarius in collaboration with H. Fetzer. Neuwied, Darmstadt: Luchterhand.

Heyneman, S. (2002). Lernziel gesellschaftlicher Zusammenhalt. Neue Aufgaben für Staaten und gesellschaftliche Organisationen [Learning goal of social cohesion: New tasks for states and societal organisations]. Vereinte Nationen, 50(1), 16-23.

Hives, T., Kozma, T., Radacsi, I., Rébay, M. (eds). (2007). Hungary. In Hörner, W., Döbert, H., von Kopp, B., Mitter, W. (eds.), The Education systems of Europe. Dordrecht: Springer, pp. 341-355.

Hochbaum, I. (1993). Neue Wege der Zusammenarbeit. Die Bildungs- und Berufsbildungspolitik in Europa nach Maastricht [New ways of co-operation: The educational and vocational-education policy in Europe after Maastricht]. Bildung und Erziehung, 46(1), 19-37.

Hörner, W. \& Nowosad, I. (2007). Poland. In Hörner, W., Döbert, H., von Kopp, B., Mitter, W. (eds.), The Education systems of Europe. Dordrecht: Springer, pp. 590606.

Janowski, A. (2007). Educational Restructuring and Change: Post-communist educational transformation in Poland. Orbis Scholae, 1(2), 80-108.

Kosová, B . \& Porubský, Š. (2007). Educational Transformation in Slovakia: The Ongoing search for a solution. Orbis Scholae, 1(2), 109-230.

Lippert, B. Sternstunde oder Stolpersteine? Erweiterung und europäische Integration. Osteuropa, 54(5-6), 47-60.

Mitter, W. (2004a). Rise and decline of education systems: a contribution to the history of the modern state. Compare, 34(4), 347-369.

Mitter, W. (2004b). Das deutschsprachige Schulwesen auf dem Territorium der heutigen Tschechischen Republik von der Allgemeinen Schulordnung 
(Maria Theresias) bis 1938 [German-medium education on the territory of the today's Czech Republic from Maria Theresia's General School Order to 1938]. In Mezinárodní konference Všeobecné vzedělávání pro všechny - International Conference Public Education for All, Praha, 2.-5. 11. 2004. Praha: Pedagogické museum J. A. Komenského v Praze, pp. 24-31.

Mitter, W. (2003). A decade of transformation: Educational policies in Central and Eastern Europe. International Review of Education, 49(1-2), 75-96.

Mitter, W. (2005). Perspektiven der Bildungspolitik in den Staaten Ostmitteleuropas. In Bachmaier, P. \& Blehova, B. (eds), Der kulturelle Umbruch in Ostmitteleuropa. Der Transformationsprozess und die Bildungs- und Kulturpolitik Tschechiens, der Slowakei, Polens und Ungarns im Kontext der internationalen Beziehungen. Frankfurt am Main: Peter Lang, pp. 33-52. (= St. Pöltner Osteuropa Studien, vol.3).

Pagden, A. (2002). Europe: conceptualising a continent. In: Pagden, A. (ed.), The idée of Europe. Cambridge: Cambridge University Press, pp. 33-54.

Průcha, J. (2007). Czech Public. In Hörner, W., Döbert, H., von Kopp, B., Mitter, W. (eds.), The Education systems of Europe. Dordrecht: Springer, pp. 166-183.

Sztompka, P. (2004). From East Europeans to Europeans: Shifting collective identities and symbolic boundaries in New Europe. European Review, 12(4), 481-496.

Švec, Š. \& Hrabinská, M. (2007). Slovak Republic. In: Hörner, W., Döbert, H., von Kopp, B., Mitter, W. (eds.), The Education systems of Europe. Dordrecht: Springer, pp. 688-706.

\section{Contact Information}

Prof. em. Dr. Dr. h.c. Wolfgang Mitter

Center for Research on Educational Quality and Evaluation

German Institute for International Educational Research

Schloßstraße 29

60486 Frankfurt am Main

Germany

mitter@dipf.de 